\title{
Motivasi Belajar Siswa Selama Pandemi dalam Proses Belajar dari Rumah
}

\author{
Lita Izzatunnisa ${ }^{1}$, Ade Suryanda ${ }^{2}$, Anisa Siti Kholifah ${ }^{3}$, Cynthia Loka ${ }^{4}$, Peralihan \\ Pertiwi Idea Goesvita ${ }^{5}$, Priscila Sindy Aghata ${ }^{6}$, Salwa Anggraeni ${ }^{7}$. \\ Pendidikan Biologi FMIPA, Universitas Negeri Jakarta \\ litanisa28@gmail.com ${ }^{1}, \underline{\text { asuryanda@unj.ac.id }}{ }^{2}, \underline{\text { anisask872@gmail.com }}$, \\ cynthialoka78@gmail.com ${ }^{4}$, tatagarciapang@gmail.com ${ }^{5}$, priscilasagatha@gmail.com ${ }^{6}$, \\ Salwa.sa528@gmail.com ${ }^{7}$
}

\begin{abstract}
Abstrak: Penelitian ini mengkaji motivasi belajar siswa selama pandemi dalam proses belajar dari rumah. Dalam proses belajar, motivasi sangat dibutuhkan. Motivasi dapat timbul dari intrinsik (dalam diri individu) maupun ekstrinsik (luar individu). Kedua faktor ini sangat penting dan berkesinambungan dalam meningkatkan motivasi siswa. Selama pandemi COVID-19, proses pembelajaran dilakukan dari rumah, sehingga motivasi belajar dapat berpengaruh dari beberapa faktor. Dari hasil penelitian yang didapat, banyak faktor-faktor yang tidak mendukung proses belajar siswa selama pandemi. Faktor-faktor tersebut, diantaranya; kemampuan teknologi, koneksi akses jaringan internet, media pembelajaran yang digunakan, kapasitas siswa untuk pembelajaran online, dan lain-lain, sehingga motivasi belajar siswa berubah menjadi menurun. Dengan demikian, dapat disimpulkan bahwa motivasi belajar siswa selama pandemi dalam proses belajar dari rumah mengalami penurunan.
\end{abstract}

Kata Kunci: COVID-19; Motivasi; Pandemi, Siswa.

Abstract: This study examines students' learning motivation during the pandemic in the learning process from home. In the learning process, motivation is needed. Motivation can arise from intrinsic (within the individual) or extrinsic (outside the individual). These two factors are very important and continuous in increasing student motivation. During the COVID-19 pandemic, the learning process is carried out from home, so learning motivation can be influenced by several factors. From the research results obtained, there are many factors that do not support the student learning process during the pandemic. These factors, among others; technological skills, internet network connections, learning media used, student capacity for online learning, and so on. Thus, it can be neglected that student motivation during the pandemic in the learning process from home has decreased.

Keywords: COVID-19; Motivation; Pandemic, Students.

\section{Pendahuluan}

Penyebaran virus COVID-19 yang sangat cepat di Indonesia maupun di dunia sangat mengkhawatirkan dan memberi dampak bagi seluruh sektor kehidupan. Pemerintah mengambil tindakan sigap dengan physical distancing. Kualitas pendidikan sangat ditantang di tengah mewabahnya virus ini. Kementerian Pendidikan turut menghimbau 
untuk diterapkannya pembelajaran jarak jauh untuk menertibkan masyarakat dalam physical distancing. Berdasarkan Surat Edaran Nomor 4 Tahun 2020 tentang Pelaksanaan Kebijakan Pendidikan dalam masa darurat penyebaran virus, Mendikbud menghimbau agar semua lembaga pendidikan tidak melakukan proses belajar mengajar secara langsung atau tatap muka, melainkan harus dilakukan secara tidak langsung atau jarak jauh.

Belajar adalah usaha yang dilakukan secara sadar untuk merubah sikap dan tingkah lakunya. Dalam upaya mencapai perubahan tingkah laku dibutuhkan motivasi. (Emda, 2017). Belajar dimaknai sebagai proses perubahan perilaku sebagai hasil interaksi individu dengan lingkungannya. Perubahan perilaku terhadap hasil belajar bersifat continiu, fungsional, positif, aktif, dan terarah (Pane, 2017). Motivasi menurut KBBI adalah dorongan yang timbul pada diri seseorang secara sadar atau tidak sadar untuk melakukan suatu tindakan dengan tujuan tertentu. Motivasi bisa timbul dari luar (ekstrinsik) maupun dari dalam individu (intrinsik). Kedua faktor ini sangat penting dan berkesinambungan dalam meningkatkan motivasi dalam belajar. Menurut Sari (2018) mengenai iklim belajar yang diciptakan pembelajaran daring turut mempengaruhi motivasi belajar siswa, jika dalam pembelajaran luring guru mampu menciptakan suasana kelas kondusif untuk menjaga motivasi belajar siswa agar pembelajaran dapat tercapai karena iklim kelas memiliki pengaruh yang signifikan dengan motivasi belajar. Hamdu (2011) mengemukakan dengan adanya motivasi, siswa akan belajar lebih keras, ulet, tekun dan memiliki dan memiliki konsentrasi penuh dalam proses belajar pembelajaran. Dorongan motivasidalam belajar merupakan salah satu hal yang perlu di bangkitkan dalam upaya pembelajaran di sekolah.

Menurut Kompri (2016) motivasi belajar merupakan segi kejiwaan yang mengalami perkembangan, artinya terpengaruh oleh kondisi fisiologis dan kematangan psikologis siswa. Beberapa unsur yang mempengaruhi motivasi dalam belajar yaitu:

1. Cita-cita dan aspirasi siswa. Cita-cita akan memperkuat motivasi belajar siswa baik intrinsik maupun ekstrinsik.

2. Kemampuan Siswa Keinginan seorang anak perlu dibarengi dengan kemampuaan dan kecakapan dalam pencapaiannya.

2. Kondisi Siswa

Kondisi siswa yang meliputi kondisi jasmani dan rohani. Seorang siswa yang sedang sakit akan mengganggu perhatian dalam belajar.

3. Kondisi Lingkungan Siswa.

Lingkungan siswa dapat berupa lingkungan alam, lingkungan tempat tinggal, pergaulan sebaya dan kehidupan bermasyarakat.

\section{Metode Penelitian}

Metode yang digunakan pada kajian ini adalah metode penelitian kualitatif. Teknik pengumpulan data menggunakan metode penelitian kualitatif dilakukan dengan cara studi literatur atau studi kepustakaan yang mengkaji teori-teori relevan dengan masalah 
penelitian. Data yang diperoleh dibaca, dianalisis, diolah, dan disimpulkan hingga menghasilkan kesimpulan.

\section{Hasil dan Pembahasan}

Berdasarkan hasil riset dari jurnal-jurnal terkait motivasi belajar selama pandemi. Studi yang menggambarkan satu Sekolah Menengah Atas di Finlandia selama pandemi COVID-19 menunjukkan temuan utama bahwa pengajaran jarak jauh telah dilaksanakan dengan sangat sukses. Namun, Siswa mengeluhkan beban kerja yang berat, kelelahan, dan beberapa siswa kehilangan motivasi (Niemi, HM, \& Kousa, P. 2020). Pandemi baru-baru ini membuktikan bahwa siswa menghadiri pembelajaran jarak jauh dalam keadaan yang sangat sulit dan seringkali tanpa pengajaran atau dukungan nyata dari guru mereka (UNESCO. 2020). Secara umum, guru yang lebih berpengalaman dan ahli TI dapat mengatasi situasi baru dengan baik (Alea et al., 2020). Dari hasil analisis mann whitney U data kuesioner dari 344 siswa SMA/SMK/MA dapat diketahui bahwa motivasi belajar siswa menurun selama pembelajaran daring (Cahyani, A. 2020). Berdasarkan hasil analisis data ditengah pandemi COVID-19 yang melanda dunia, banyak hal yang tidak menjadi alasan mahasiswa untuk memiliki motivasi belajar yang tinggi (Fitriyani, Y. 2020).

Tabel 1. Deskripsi Pembahasan Penurunan Motivasi Belajar Selama Pandemi Sekolah Keterangan

Menunjukkan bahwa pembelajaran jarak jauh yang diterapkan pada masa pandemic COVID-19 berjalan dengan baik dan sesuai apa yang diharapkan, hanya saja seiring berjalannya waktu motivasi beberapa siswa mengalami

SMA di Finlandia kemunduran. Karena jangka waktu yang sudah cukup lama dan fasilitas beberapa siswa yang tidak selalu memadai atau menunjang dalam menjalankan pembelajaran jarak jauh ini menjadi alasan mengapa beberapa siswa mengalami kesulitan untuk menginterpetasikan materi yang dipelajari.

Sebanyak 344 responden dari 21 provinsi yang ada di Indonesia yang berjumlah sebanyak 92 responden siswa laki-laki dan 252 responden siswa perempuan. Lebih dari $50 \%$ siswa mengalami penurunan motivasi belajar dengan metode pembelajaran jarak jauh, menurut para siswa suasana dari ruang kelas dan rumah menjadi salah satu penyebab mengapa motivasi yang mereka miliki mengalami

SMA/SMK/MA yang ada di Indonesia penurunan. Selanjutnya, $61 \%$ penyebab menurunnya motivasi belajar beralasan karena tidaklah mudah bagi para siswa menemukan waktu yang tepat untuk mengulas atau mempelajari kembali materi-materi pelajaran yang sudah diajarkan. Lingkungan keluarga yang terkadang tidak kontributif menjadi penghambat untuk menyesuaikan waktu belajar bagi siswa. Memang sudah seharusnya di masa pandemic COVID-19 ini, lingkungan keluarga harus 
bernuansa saling mendukung dan menguatkan satu sama lain.

\section{Motivasi Belajar}

Perbedaan individu dalam kemampuan dan motivasi untuk belajar telah lama dianggap sebagai prediktor penting dari efektivitas pembelajaran dan pelatihan (Campbel, 1989; Goldstein, 1993; Noe, 1986; Noe \& Schmitt, 1986). Motivasi belajar telah didefinisikan sebagai kesediaan untuk menghadiri dan mempelajari materi yang disajikan dalam program pengembangan (misalnya, Noe, 1986). Sedangkan kemampuan menjelaskan apa yang dapat dilakukan individu, motivasi untuk belajar mempengaruhi proses pengambilan keputusan yang menentukan arah, fokus, dan tingkat usaha yang akan diterapkan individu pada aktivitas pembelajaran (Noe, Wilk, Mullen, \& Wanek. 1997). Untuk itulah banyak peneliti yang mengkonseptualisasikan dan mengukur motivasi belajar dengan menggunakan pendekatan self-efficacy. Langkah-langkah ini berfokus pada persepsi diri individu tentang efektivitas dan sangat cocok untuk memprediksi seberapa baik kinerja individu (Mathieu \& Martineau, 1997). Dikonseptualisasikan sebagai sikap individu yang dapat ditempa, motivasi untuk belajar, menyarankan Noe et al, mempengaruhi proses pengambilan keputusan peserta pelatihan, yang pada akhirnya berdampak pada efektivitas pelatihan dan upaya pembelajaran (Noe, 1986; Noe \& Schmitt, 1986 ; Noe et al., 1997). Lebih lanjut, hubungan positif antara motivasi untuk belajar dan belajar telah menjadi satu yang kuat (misalnya, Colquitt \& Simmering, 1998; Colquitt et al., 2000; Mathieu, Tannenbaum, \& Salas, 1992; Noe \& Schmitt, 1986). Colquitt dkk. (2000) meta-analisis 106 studi motivasi belajar dalam upaya untuk mendapatkan nilai populasi untuk variabel individu dan situasional yang umumnya diakui sebagai terkait dengan motivasi pelatihan. Mereka menemukan bahwa karakteristik disposisional, sikap, dan situasional semuanya merupakan prediktor motivasi belajar.

\section{Kapasitas Siswa untuk Pembelajaran Online}

Pembelajaran online membutuhkan keterampilan belajar tingkat lanjut dan strategi motivasi. Motivasi bisa dari dalam atau luar, dan biasanya keduanya dibutuhkan.

Motivasi batin melibatkan pertumbuhan ketika pembelajaran itu bermakna. Lulus pembelajaran penting untuk motivasi luar. Siswa juga membutuhkan keterampilan manajemen kehidupan - bagaimana mereka mengatur hari-hari mereka sendiri, menyeimbangkan jarak sekolah dan waktu senggang, dan belajar mempertahankan kesejahteraan mereka sendiri.

\section{Manajemen Diri Siswa dalam Pembelajaran}

Tanggapan siswa terhadap kuesioner pengajaran jarak jauh oleh Niemi, HM, \& Kousa, P. memberikan bukti bahwa pengajaran jarak jauh telah dilaksanakan dengan sukses. Banyak siswa yang kelelahan, dan motivasi mereka menurun selama masa pembelajaran jarak jauh. Beberapa siswa mengeluhkan beban kerja yang terlalu berat dan berdampak negatif pada motivasi mereka. Bahkan siswa yang merasa pembelajarannya berjalan dengan baik mengalami masalah dengan manajemen pembelajaran dan motivasi. Namun, guru berpendapat bahwa siswa termotivasi dan pembelajaran jarak jauh berjalan dengan baik. Ketika siswa berbicara tentang motivasi mereka, yang mereka maksud 
adalah motivasi batin, dan guru berbicara tentang motivasi luar dan hasil siswa. Menurut Sayk1l1 (2018), bahkan siswa yang berprestasi dengan motivasi yang baik dan keterampilan mengatur diri sendiri dapat merasa kesulitan belajar jarak jauh, mengisolasi, dan mengecilkan hati. Penelitian sebelumnya juga telah menegaskan bahwa siswa membutuhkan keterampilan manajemen diri dalam pembelajaran jarak jauh (misalnya, Artino \& Stephens, 2009), karena pengaturan diri adalah kunci untuk motivasi dan prestasi yang lebih baik (Wolters, 2003). Lingkungan belajar yang fleksibel dengan pilihan berbeda untuk kebutuhan individu telah disarankan (Daher \& Shahbari, 2020) karena dapat meningkatkan motivasi siswa, rasa kemandirian, dan keterampilan mengatur diri sendiri (Simons et al., 2019). Masalah teknologi dalam pembelajaran jarak jauh juga mempengaruhi motivasi belajar siswa (Ozkara \& Cakir, 2018). Pada awalnya, siswa studi tidak memiliki banyak masalah dengan teknologi, tetapi kemudian masalah teknologi muncul dalam tugas dan ujian. Yang mengkhawatirkan, hingga sepertiga siswa menghabiskan lebih banyak bantuan daripada yang mereka terima. Yang lebih sulit daripada masalah yang disebabkan oleh teknologi adalah kurangnya hubungan sosial. Siswa merindukan pengajaran tatap muka dan teman. Hal ini menegaskan penelitian sebelumnya yang menemukan bahwa siswa cenderung lebih termotivasi jika mereka dapat berkomunikasi secara langsung (Ozkara \& Cakir, 2018). Menurut sebuah studi baru-baru ini, siswa sekolah menengah melewatkan kursus tradisional karena mereka menganggapnya lebih memotivasi, menyenangkan, mudah dipahami, dan penting secara sosial (Pınar \& Dönel, 2020). Dalam studi ini dan sebelumnya, guru sepakat dengan siswa bahwa interaksi aktif sangat penting dan tidak dapat digantikan oleh pembelajaran jarak jauh (Foti, 2020). Dalam studi ini, guru melewatkan spontanitas interaksi yang diberikan oleh pengajaran tradisional. Mereka juga mengklaim bahwa interaksi tersebut lebih dipaksakan dan dibuat-buat.

\section{Media Pembelajaran}

Penggunaan media pembelajaran bertujuan untuk memudahkan siswa dalam memahami materi pelajaran (Abdo \& Semela, 2010; Kadzera, 2006) dengan memberikan pengalaman belajar yang berbeda. Diharapkan dapat merangsang minat dan motivasi belajar siswa (Aini, 2013; Arsyad, 2014; Dinh, 2019). Media pembelajaran yang paling sering digunakan guru adalah video pembelajaran, baik yang diunduh dari YouTube maupun video pembelajaran yang dibuat guru sebelum Pandemi COVID-19. Selain video, WhatsApp, Google Forms, Worksheets, YouTube, dan Zoom juga berfungsi sebagai media penyampaian materi pembelajaran. Guru mengirimkan materi pelajaran menggunakan WhatsApp, Google Formulir, dan Lembar Kerja kepada orang tua siswa, yang selanjutnya diberikan kepada siswa. Metode pengajaran yang paling umum digunakan adalah format tanya jawab (Q\&A) (Cao et al., 2010). Guru melaksanakan metode Tanya Jawab dan diskusi menggunakan Zoom, Google Classroom, dan PowToon.

\section{Kemampuan Teknologi Pengajar}

Pengalaman teknologi guru dalam lingkungan online juga menjadi salah satu tantangan yang menentukan kelancaran kegiatan pembelajaran (Conrad \& Donaldson, 2011; Ko \& Rossen, 2017; Watson, 2020). Kapasitas guru dalam menggunakan teknologi sangat penting karena tantangan teknis dalam pembelajaran jarak jauh memiliki pengaruh negatif terhadap motivasi dan pembelajaran siswa (Ozkara \& Cakir, 2018). Juga 
mengkhawatirkan bahwa situasi krisis meningkatkan ketimpangan di antara siswa. Hal ini juga mengkhawatirkan bahwa guru dan siswa tidak menyadari ketidaksetaraan digital, terutama karena ketimpangan digital yang meningkat akibat pandemi (Hall et al., 2020).

\section{Kendala Siswa}

Menurut Sikirit (2020), kendala paling signifikan yang dihadapi siswa saat belajar di rumah adalah kurangnya akses internet dan perangkat elektronik. Karena tidak semua siswa memiliki fasilitas pembelajaran tersebut, terutama bagi keluarga yang orang tuanya mengalami kesulitan ekonomi, kehilangan pekerjaan, dan daerah yang masih sulit dijangkau untuk akses internet. Yangmana ketersediaan fasilitas pembelajaran seperti handphone / laptop dan kuota data internet serta jaringan internet menjadi sangat penting dalam pelaksanaan pembelajaran. Ketidakstabilan jaringan yang mengakibatkan sering terjadi keterlambatan, suara guru dan bahan ajar tidak sinkron, mereka tidak dapat mengambil kelas ketika wi-fi tidak terhubung sehingga interaksi tidak memungkinkan dan kualitas lingkungan pendidikan buruk, konten tidak tersampaikan secara akurat, interaksi langsung tidak dimungkinkan, penyediaan data yang tidak mencukupi, ketidakpuasan dengan perubahan tugas, kendala pada proyek tim, prestasi akademik yang berkurang, desain kelas yang tidak siap, pemahaman kelas yang berkurang, ketidakpuasan kelas, ketidakpuasan penilaian, ketidakpuasan administratif, ketidakpuasan dengan pembentukan hubungan, dan ketidakpuasan dengan lingkungan pendidikan.

\section{Kesimpulan dan Saran}

Selama pandemi COVID-19, siswa menghadiri pembelajaran jarak jauh dalam keadaan yang sangat sulit dan seringkali tanpa pengajaran atau dukungan nyata dari guru mereka. Kemudian, siswa mengeluhkan beban kerja yang berat, kelelahan, dan beberapa siswa kehilangan motivasi. Beban kerja dan kelelahan bisa dari hal bagaimana mereka mengatur hari-hari mereka sendiri, menyeimbangkan jarak sekolah dan waktu senggang. Masalah teknologi dalam pembelajaran jarak jauh juga mempengaruhi motivasi belajar siswa. Pada awalnya, siswa studi tidak memiliki banyak masalah dengan teknologi, tetapi kemudian masalah teknologi muncul dalam tugas dan ujian. Dan itu juga berpengaruh bagi siswa yang memiliki teknologi yang tidak mendukung. Yang lebih sulit daripada masalah yang disebabkan oleh teknologi adalah kurangnya hubungan sosial. Siswa cenderung lebih termotivasi jika mereka dapat berkomunikasi secara langsung.

Kapasitas guru dalam menggunakan teknologi juga sangat penting karena tantangan teknis dalam pembelajaran jarak jauh memiliki pengaruh negatif terhadap motivasi dan pembelajaran siswa. Kemampuan guru menggunakan teknologi berkaitan dengan media pembelajaran yang dilaksanakan selama proses belajar. Metode pembelajaran dalam media pembelajaran di PJJ dapat merangsang minat dan motivasi belajar siswa. Dan faktor terakhir yaitu kurangnya akses internet dan perangkat elektronik, ketidakstabilan jaringan yang mengakibatkan sering terjadi keterlambatan, suara guru dan bahan ajar tidak sinkron, mereka tidak dapat mengambil kelas ketika wi-fi tidak terhubung sehingga dalam interaksi pembelajaran menjadi terganggu dan dapat menurun motivasi belajar.

Dalam hal ini, para peneliti dapat mengembangkan media dan sarana pembelajaran lebih lanjut untuk memberikan suasana dalam proses belajar menjadi efektif dan membangunkan motivasi siswa lebih meningkat. 


\section{Daftar Pustaka}

Alea, L. F. (n.d.). Teachers' COVID-19 Awareness, distance learning education experiences and perceptions towards institutional readiness and challenges. International Journal of Learning, Teaching and Educational Research, 19(6), 127-144.

Artino, A. \&. (2009). Motivasi akademik dan pengaturan diri: Analisis komparatif tentang mahasiswa sarjana dan pascasarjana belajar online. Internet dan Pendidikan Tinggi, 12, $146-151$.

Cahyani, Adhetya. (2020). Motivasi Belajar Siswa SMA pada Pembelajaran Daring di Masa Pandemi Covid-19. Jurnal Pendidikan Islam, 3(1), 138.

Campbell, J. (n.d.). Agenda teori dan penelitian. In Pelatihan dan pengembangan dalam organisasi (Di IL Goldstein ed., pp. 469-486). San Francisco: Jossey-Bass.

Colquitt, J. \&. (1998). Conscientiousness, goal orientasi, dan motivasi belajar selama proses pembelajaran: Sebuah studi longitudinal. Jurnal Psikologi Terapan, 83, 654-665.

Colquitt, J. L. (2000). Menuju inteteori gratif motivasi pelatihan: Sebuah analisis jalur metaanalitik dari 20 tahun penelitian. Jurnal Psikologi Terapan, 85, 678-707.

Daher, W. \&. (2020). Identitas siswa menengah di kelas virtual.

Emda, Amna. (2018). Kedudukan motivasi belajar siswa dalam pembelajaran. Lantanida Journal, 5(2), 172-182.

Hamdu, Ghullam \& Agustina, Lisa. (2011). Pengaruh Motivasi Belajar Siswa Terhadap Prestasi Belajar IPA di Sekolah Dasar. Jurnal Penelitian Pendidikan, 12 (1) https://pusdiklat.kemdikbud.go.id/surat-edaran-mendikbud-no-4-tahun-2020-tentangpelaksanaan-kebijakan-pendidikandalam-masa-darurat-penyebaran-corona-virusdisease-covid-1-9/

Kompri. (2016). Motivasi Pembelajaran Perspektif Guru dan Siswa. Bandung: PT Rosda Karya.

Mathieu, J. \&. (1997). Individu dan situasi pengaruh nasional dalam motivasi pelatihan. In Meningkatkan efektivitas pelatihan dalam organisasi kerja (pp. 193-222).

Motivasi. 2020. Pada KBBI Daring. Diambil 24 November 2020, dari https://kbbi.web.id/motivasi

Niemi, H. M. (2020). A case study of students' and teachers' perceptions in a Finnish high school during the COVID pandemic. International Journal of Technology in Education and Science (IJTES), 4(4).

Noe, R. \&. (n.d.). Pengaruh sikap peserta pelatihan tentang efektivitas pelatihan: Uji model. . Psikologi Personalia.

Noe, R. (1986). Atribut dan sikap peserta pelatihan: Diabaikan pengaruh pada efektivitas pelatihan.

Pane, Aprida \& Dasopang, Muhammad Darwis. (2017). Belajar dan Pembelajaran. FITRAH Jurnal Kajian Ilmu-ilmu Keislaman, 3(2) 
Pusdiklat Pegawai Kementerian Pendidikan dan Kebudayaan. "Surat Edaran Mendikbud No 4 Tahun 2020 Tentang Pelaksanaan Kebijakan Pendidikan Dalam Masa Darurat Penyebaran Corona Virus Disease (Covid-19),” 24 Maret 2020.

Sari, Dewi Permata \& Rusmin, A. R. (2018) .Pengaruh Iklim Kelas Terhadap Motivasi Belajar Peserta Didik Di Sman 3 Tanjung Raja. Jurnal Profit Kajian Pendidikan Ekonomi dan Ilmu Ekonomi, 5(1): 80-88.

Sayk1l1, A. (2018). Distance education: Definitions, generations, key concepts and future directions. International Journal of Contemporary Educational Research, 5(1), 2-17.

Simons, J. L. (2019). Keberhasilan lulusan pembelajaran jarak jauh dan peran intrinsik motivasi. Buka Belajar: Itu Jurnal dari Buka, Jarak dan e-Learning.

Wolters, C. (2003). Peraturan motivasi: Mengevaluasi aspek belajar mandiri yang kurang ditekankan. Psikolog Pendidikan, 38, 189-205. 